\title{
Right Product, Wrong Packaging: Not 'Constitution', but 'Constitutional Charter'
}

\section{John Law}

\section{Introduction}

This article seeks to locate the principal cause of Europe's current ratification crisis in the overly-ambitious inclusion of the word 'Constitution', standing alone as a noun, in the title of the document produced by the Convention on the Future of Europe. Whilst the content of the document was measured and appropriate, it is argued, the label given to it was not ${ }^{1}$.

The article examines the validity of the proposition that the text is, in fact, an 'EU Constitution' - as the media have portrayed it and as its title, Treaty Establishing a Constitution for Europe, would indeed seem to suggest. It finds that, whilst not entirely beyond the realms of theoretical possibility, the re-definition of the very concept of a Constitution that would be required to admit such a styling (i.e. a broadening to encompass a multi-State conception of the term) has not been fully articulated by Europe's political leaders - or even recognised or acknowledged by them, more than circumstantially.

However, following such a path, the article argues, would anyway now be unwise. For seeking to re-engineer the meaning in the public mind of so entrenched and important a notion, one with such powerful historic associations, would represent a hazardous and potentially fatal route to take at the second ratification attempt.

On this basis, the article concludes, the European Council would be best advised at this juncture to take a path of lesser resistance. Such a course could involve making a modest 'clarifying' revision to the title of the text, replacing the single word 'Constitution' with the two words 'Constitutional Charter'. The full modified title would thus read: Treaty Establishing a Constitutional Charter for Europe. Crucially, if this option were chosen, the media would have to adapt their shorthand styling of the document from 'EU Constitution' to 'EU Constitutional Charter', in order to keep pace with the advancing political debate and give accurate expression to the change in wording of the title that had taken place. In this way the basic 'sound-bite' message would be transformed, sending out a clear signal to voters that significant change had been implemented.

Through this alteration, the appearance given by the text would be brought back into line with its underlying substance. For the term 'Charter' is recognised in law to be in the order of a treaty between States; so adoption of the term would help clarify the fact that the EU will remain by nature a system of multiple States upon ratification of the text, rather than transforming into a single State in its own right (this can be deduced from analysis of the detailed provisions, as will be shown). Introduction of the term Constitution standing alone as a noun, it must be recognised, did indeed misleadingly seem to imply to the public the birth of a State - the major weakness at the first ratification attempt - even if for informed observers it was plainly apparent that this was not the case. 
Since the start of 2007 under the German Presidency of the Union, moves have been underway to canvas possible amendments to the underlying articles of the document. A very wide range of discordant proposals have, however, emerged from within the member States, with at least four camps identifiable: those arguing for an enlarged text, those for an unchanged text, those for a smaller text and those for no text at all. On the basis of the prevailing evidence, therefore, a stalemate looks the most likely outcome from the current round of negotiations.

In this circumstance, confronting the resulting impasse through amending the title could prove an attractive recovery option, when considered in combination with political declarations of the European Council to respond to French and Dutch concerns (following the precedent set at Maastricht and Nice in the cases of the Danes and Irish respectively ${ }^{2}$ ). After all, the initial document remains a package deal around which all twenty-seven countries had managed to agree; and so far the French and Dutch have yet to identify a single credible complaint to do with the text itself that withstands close scrutiny.

The question 'what was wrong with the initial draft?', it seems, was never satisfactorily answered. The fault lay first time round with the title, and the right thing to be doing at this juncture is to correct this deficiency. The text was not a 'Constitution', as we traditionally understand the term, and the text was not a significant departure from the status quo, as compared with previous treaties such as the Single European Act (SEA) and Maastricht which had instituted major reforms. As such, it did not require referenda to ratify. Now that this particular jack is out of its box, however, it is up to politicians to explain what went wrong (i.e. an inappropriate and misleading styling) and either: (i) set out why a text with an amended title should be supported by the public at referenda on a second occasion; or (ii) go down the route of parliamentary ratification, which is arguably the path that should have been taken on the first attempt.

The article proceeds in the following manner. First, the nature of the problem now confronting Europe is analysed, through an examination of the way the title of the text was arrived at in the Convention. Secondly, relevant lessons are recalled from the ratification debates on the Maastricht Treaty of the early 1990s. Thirdly, the premise of the title that the document 'establishes a Constitution' is subjected to investigation. To this end, a number of competing interpretations of the term 'Constitution' and of the word 'establishing' are identified, leading to the construction of a matrix of four possible permutations. Relevant conclusions are drawn from the analysis and recommendations made for achieving greater coherence and clarity. Fourthly, the article identifies two possible shorthand characterisations for the text as credible alternatives to the designation 'EU Constitution', 'EU Constitutional Treaty' and 'EU Constitutional Charter', and establishes long form titles that might give rise to each. It proposes the latter as the more promising of the two potential remedies for Europe's current malady and gives reasons to support this choice.

\section{Getting what went wrong right}

The first step towards resolving the current dilemma must be to establish clearly the nature of the problem: what went wrong at the first ratification attempt.

Whilst there has been much discussion of the causes of the failed French and Dutch referenda in 2005 (Jeffery 2005; Nicolaidis 2005; Piris 2006), few analyses have identified an inappropriate naming of the text as the key common problem with anything more than passing comment; none has so far conducted a thorough investigation into the dynamics of this question.

It is argued here that an emphasis upon deficiency in the wording of the title is justified, as commentary on the two failed plebiscites has brought out clearly the lack of any one common and coherent complaint to do with the substance of the text itself. Instead, the political debates in the two countries focused on a range of varied concerns, often more of domestic than European relevance, with less overlap between the debates than is commonly 
supposed. In this context, the referenda became, to a significant extent, simply opportunities to protest against unloved incumbent national governments ${ }^{3}$.

The rapid degeneration of the ballots into occasions for second-order voting was, the article suggests, a direct consequence of confusion over the nature of the text, stemming from ambiguity in the title: what exactly citizens were being asked to vote for was not clear. Uncertainty on this 'top level' issue of prime importance - the central 'message' offered by the text - arguably served to 'switch off' voters at the very first hurdle. Their attention, goodwill and trust once lost could not be regained.

So, it is appropriate to begin the analysis in this section by returning to the drafting of the text in the Convention and examining, in particular, how the title of the document was decided upon. We take up events after the 'listening phase' of the first five months has been completed and the 'study phase' is underway in the Autumn of 2002.

The most striking feature of the output coming from the working groups at this still early point in the Convention's life had been how conservative many of the proposals had seemed - indeed, how the minimalist, lowest common denominator view (more often than not, the British view ${ }^{4}$ ) had appeared to dominate proceedings. He who holds the pen wields the power, runs the saying, and the UK had managed to install Sir John Kerr in the key post of Secretary General to the Convention. Though technically an administrative office only, Kerr quickly established himself as Convention President Valéry Giscard d'Estaing's right hand man and most trusted confidant. His influence was clearly considerable, being the critical channel through which Giscard would dominate proceedings through control of both working procedure and the technical drafting. With Euro-sceptics as well as Euro-philes present among the delegates, and the candidate countries of Eastern Europe fully represented, the impression had steadily grown that the 'inter-governmentalist' tendency within the Convention was at least matching up to, if not triumphing over, the 'federalist' centralising impulse. On the directing Praesidium, the French and British inclination, through Giscard and Kerr, seemed very much in control, and this suspicion appeared to receive confirmation in the two key institutional innovations proposed, which both concerned beefing-up the body representing the member States through (i) the creation of a post of permanent 'President' of the European Council, and (ii) the elevation of the High Representative for the Common Foreign and Security Policy (CFSP) to the status of 'Union Foreign Minister'.

The idea that the whole project was only marginally more than an exercise in house-keeping rather than a quantum leap - mid-way through the Convention's life appeared justified; and commentators have indeed reflected this appreciation in their writings after the conclusion of proceedings. Menon, for example, observed '... the treaty amounts to an important tidyingup exercise. ... All in all, it is far less radical than several treaties that have preceded it, and pales into insignificance when compared to the reforms achieved by the 1986 Single European Act ...' (Menon 2004: 29). Patten, in similar vein, concluded '... the treaty recognised that we had gone about as far as we could or should in developing supranational policies and institutions. The real world of twenty-five nation states and national parliaments had intervened. The supranational bargains already struck were not to be disparaged, but enough was enough. ... The treaty sought rightly to draw a line in the sand so far as further integration is concerned' (Patten 2005: 129-130).

There was, furthermore, plenty of evidence emerging to support this view as the detailed articles were gradually fleshed out. The phrase 'ever closer union' was re-formulated (and in the process, apparently, down-graded); there would be no move proposed to majority voting in foreign policy and defence; similarly, there would be no move on tax harmonisation; the early general statements, such as the definition of the Union and the formal elaboration of a principle of 'conferral', appeared to give primacy to the member States as the bed-rock of the EU system and mainspring of legitimacy; and the draft even introduced an express unilateral right of withdrawal for the member States (Article I-60), an innovation where before the Treaty on European Union (TEU) had been silent. 
This last point appeared to lay to rest once and for all the spectre of the imminent birth of a single pan-European State. For, as Piris ${ }^{5}$ has observed, the removal of ambiguity on the secession issue illuminated in sharp relief the emerging nature of the beast: '.. one may note that such a right normally exists in confederations of States but never in federal States. Therefore, this provision on withdrawal could be seen as clarifying a basic issue, i.e. that the Union is actually a voluntary association between States which remain sovereign as to the question of whether or not they remain in that association' (Piris 2006: 130). The introduction of Article 1-60, it seems, was no trivial matter, even if the depth of its apparent significance may not have been fully appreciated by all of the Convention delegates ${ }^{6}$.

There were, of course, a number of significant compensating advances proposed, strengthening the supra-national aspect of the Union: codifying the legal principles of 'primacy' and 'direct effect'; abandoning the 'pillar' structure of the TEU in favour of a unified framework; the awarding of legal personality to the Union; the inclusion of the European Charter of Fundamental Rights; and a legal base for an EU diplomatic service, the European External Action Service. However, the overall impression was more one of balance between elements strengthening the hand of the member States and those bolstering the Community aspect, than it was of untrammelled centralisation such as had clearly animated both the SEA and TEU.

Set against this background - of only marginal movement from the status quo with much good 'tidying-up" - Giscard's manoeuvrings in the final days of the Convention to forge a product that would mirror the output of the Philadelphia Convention appeared somewhat detached from the underlying reality.

Indeed, from the moment the single but hugely significant word 'Constitution', standing on its own, was incorporated in the title of the Convention's draft document late in the day, replacing what had before been a more subtle descriptive adjective ${ }^{8}$, the whole enterprise took on the feel of an accident waiting to happen. It was simply a question of time, it seemed, before the locomotive would hit the obstacle of a sceptical public, lying stationary across the track some way distant. Not if there would be a crash; but simply when.

Ziller captures well the train of events leading up to this shift of wording: '... The use of the term "Constitution" in discussing Europe's future did not have unanimous support ... there was a long-standing preference for the more ambiguous expression "Constitutional Treaty". When Convention President Valéry Giscard d'Estaing presented the initial outline, or squelette, of the text, almost no one noticed that both the cover page used on 28 October 2002 and the press release of the next day bore the title "Treaty establishing a Constitution for Europe".... By the end of the Convention's proceedings in June of 2003, it seemed to be taken for granted that the Intergovernmental Conference (IGC) would use the term "Constitution" and the Convention's text was even published under the title "Constitution for Europe"'. (Ziller 2005: 16-17).

In fact, the outline document of 28 October 2002 had borne both formulations: 'Preliminary draft Constitutional Treaty' on the cover page of page one, and 'Treaty Establishing a Constitution for Europe' heading the actual draft skeleton text on page two (Convention 2002: 1-2). Such was the legerdemain by which the formerly taboo word was slipped into proceedings, bringing it into the Convention mindset, if not open usage, half-way through the Convention's life and preparing the ground for its eventual adoption in the title of the final text.

Giscard himself had plainly stated initially that usage should be otherwise (see Footnote 8). So this seems a clear-cut case of politics in action. This author has heard from a prominent member of the Convention that it was a firm objective of Giscard's at the start to have the final product emerge as a 'Constitution' (in tune with the wishes of this member and certain other leading figures within the Convention, and perhaps responding to pressure from them), even if this was not politically achievable at the beginning of the Convention. He told the member not to worry on this score; the term would emerge 'like a rabbit out of a hat' towards 
the end of the process. Thus, it seems self-evident that the phased alteration of the wording of the title was an intentional strategy; it would be naïve to assume otherwise.

The focus upon the role played by the President here thus does not represent undue attention. The finessing of the wording was a subtly deployed and, indeed, barely discernible tactic - but it was one, it is argued, which was deliberate. It is beyond doubt that Giscard did an admirable job of work in steering the Convention through to producing a single coherent draft text; in the respect, however, in which he took upon himself the task of selecting the final - and fatal - form of wording, it seems clear where responsibility for the ratification mixup that followed lies. This might, without the benefit of hindsight, be considered an easy mistake to have made. Time has shown, however, that it was where the mistake crept in nevertheless ${ }^{9}$.

Was it not to be guessed in advance, in the light of the stormy ratification debates at the time of Maastricht, that giving Europe its own 'Constitution', widely seen as the very embodiment of essential sovereignty, would be for even moderate Euro-sceptics like waving a red rag before a bull? The existence of a basic prior political context for adoption of the term is not denied, following the initial proposal by the German Foreign Minister Joschka Fischer and subsequent support from French President Jacques Chirac - the latter from the somewhat counter-intuitive angle of its potential to limit the growth of Community competence (Church and Phinnemore 2006: 19; Ziller 2005: 16). Nevertheless, the Convention President's extension of the notion of 'constitutionalisation' to its fullest scope was unwise. It was a move for which the peoples of Europe were not yet ready; and the hostile reaction should not have come entirely as the surprise that it appears to have been.

In the respect, therefore, that the final choice of wording of the title seems to have been a step too far, out of tune with the underlying substance, we can conclude this first section by identifying the inappropriate styling of the text firmly as the principal cause of the difficulties with ratification experienced in the French and Dutch referenda of 2005. A clearer and more precise title, better reflecting the actual nature of the text and free of unhelpful connotations, may not have removed all opposition. However, it might have been sufficient to allow a calmer and more rational debate, focussed on the merits of the document; and this might, in turn, have been enough to tip the balance of forces in favour of a Yes vote, first in France, and then in the Netherlands afterwards ${ }^{10}$.

\section{Re-learning the lessons of Maastricht}

It seemed in 2003 that the lessons of Maastricht a decade prior had not been properly taken to heart. On this occasion, the people had sent two very loud and clear messages to their elected leaders.

'Do less and do it better' was the first and most audible demand, running counter to the apparently remorseless expansion of competences contained in the TEU which threatened to lead in the long run to a 'super-State', almost universally recognised as unwanted. The clamour was for existing powers to be used better before adding more: less waste of public money through fraud, greater administrative efficiency within the bureaucracy, less burdensome regulation and application of the (then new) subsidiarity principle.

The second clear message was for better communication between governors and the governed. Maastricht was the occasion when the public had first connected with, or woken up to, in a meaningful way the process of European integration happening around them and the project ceased to be a passive, élite-led and technocratic affair going on 'behind the backs' of the people (or perhaps, more correctly, without their knowledge and consent). The SEA had not been widely discussed or scrutinised in pubic; the TEU was. Certainly because it was not expected in 1992 that there would be wide public demand for the Maastricht text, a consolidated official version (a 'clean' version) was not available prior to the ratification debates - just the TEU as signed, containing only the untidy and partial amending clauses. A major part of the negative public reception at that time stemmed from the resulting difficulty 
in reading the text: those who tried found they could not do so with any ease. The impression of an 'incomprehensible' text once formed was hard to dislodge.

Happily, the European institutions grasped this message in the 1990s and would not make the same mistake at Amsterdam and Nice. They appeared to take on board the novel requirement to communicate clearly and directly with the citizen. A decade later, however, the prime importance of good communication appeared to have been forgotten - or at least lost sight of. In announcing the adoption of a draft Treaty Establishing a Constitution for Europe, the Convention introduced a claim which seemed to the public both of huge import and yet strangely fanciful in the same breath. Not only would voters in time declare themselves sceptical and confused about what exactly was being proposed; many commentators openly expressed their concern and doubts and a debate started as to the exact nature of the text whether Constitution or treaty, or both (Eleftheriadis 2004; Donnelly 2005; MacCormick 2005: 17).

The farcical nature of the public exchanges that followed in the wake of publication of the Convention's document at times bordered almost on the surreal. In the UK, the leading proEuropean and former Conservative Deputy Prime Minister, Michael Heseltine, appeared to land himself in difficulty by openly expounding the view that the text was not a Constitution: '... anti-Europeans have let their imagination run wild. ... Start with the canard that this treaty is a constitution: it is not. A constitution sets out the basic laws of a state; this is a treaty - an agreement between governments - that sets out the basic rules of the European club, which member states have freely joined, and includes provisions for them to leave if they wish to' (Heseltine 2004). This approach offered an open goal to the Euro-sceptics: Conservative MEP Daniel Hannan retorted simply that the words 'establishing a Constitution' were clearly stated in the title and invited his opponent actually to read the document. Unsurprisingly, the British public were left baffled by this exchange, and sceptical as to the coherence of the proEuropean case. The essential nature of the document under discussion, it seemed, was by no means clear even to its strongest supporters.

Interestingly, in taking such a line, Heseltine was following in the foot-steps of none other than Kerr a year earlier. In reviewing Norman's synopsis of the Convention, Kerr had written: '... Of course, The Accidental Constitution is something of a misnomer. It is not a real constitution and it was not a real convention. Unlike Philadelphia in 1787, a plenipotentiary constituent assembly, Valéry Giscard d'Estaing's convention on the future of Europe had no mandate to lay the foundation of a state, and it did not. Instead it drafted a treaty - an agreement between sovereign states - to simplify and replace the current confusion of treaties. It makes no claim ("We, the people ... ") to grassroots legitimacy, bypassing states and governments' (Kerr 2003). The characterisation of the Convention's title as a 'misnomer' by so senior a figure at the very heart of dealings is highly revealing - and can only, it seems, be taken to indicate a radical difference of view between Giscard and his loyal lieutenant over the appropriateness of the final wording. This is, however, no small matter. Whether the text is or is not a Constitution, must be recognised as being of fundamental importance to the citizen in assisting him to determine the exact nature of the document under consideration and its likely impact. No consumer would buy a product in the marketplace whose nature was not crystal clear and certain. When buying a car, for example, he or she would want to be sure that it is actually a car - and not a lawnmower in disguise. Similarly, clarity of designation was, and will remain, a vital factor in referenda to secure ratification of the current European political document. Mere technicality it is not (Church and Phinnemore 2006: 34).

Piris echoes this concern, observing that ambiguity over the name led to uncertainty about the document's effects in the mind of the voter: whether at heart now a tidying-up exercise (even if an 'important' one) or a major departure, was no longer clear. He remarks: '... one might think that instead of clarifying the debate on Europe for the citizens, ... the name "Constitution for Europe" has confused the elements of the choice given to the voters in the referenda: did they have to vote for a strengthening of the EU as it is or for an EU radically transformed into a new project? Strong efforts of explanation had to be made on the part of national governments and political parties to clarify the debate. Obviously, these efforts have not been sufficient' (Piris 2006: 7). 
When confusion reigns, sadly, we all get wet. In the respect, therefore, that the Convention's leadership forgot the lessons of Maastricht and brought a significant - and unnecessary element of uncertainty into the whole project through last-minute finessing of the title, the crisis would appear to have been one largely self-generated.

\section{To be, or not to be, a Constitution ...}

We are led, thus far in the discussion, to believe that it was a mistake to include the word 'Constitution', standing alone as a noun, in the document's title; that Heseltine and Kerr were right; that the document was misnamed; and that it is not actually a Constitution.

What, however, is the analytical justification for this line of thinking? We need to look in more detail at the proposed title and examine at the conceptual level the validity of the proposition it makes: that a treaty can, in fact, establish a Constitution; and that this document is both a treaty and a Constitution.

A good place to start is by considering what is meant by the term 'Constitution'. Two distinct approaches to defining the term can be identified: first, a Constitution as the founding document of a State; and, secondly, a Constitution as the founding document of either a single State or a multi-State political system.

\section{Definition (i): A Constitution as the Founding Document of a State}

We begin with a narrow definition of the term: a Constitution as the founding document of a State. Ziller brings out the central point that this is the widely accepted (consensus) definition prevailing today. He says: '... The term Constitution - the root word for which is common to all romance languages, from English to Swedish (translated as Verfassung in German and forvatning in Danish but as grondwet, i.e., "fundamental law", in Dutch) - is generally associated with the concept of the State (rather than international organisations). This association is frequently taken for granted by a majority of politicians, jurists, social scientists and, above all, ordinary citizens' (Ziller 2005: 15). Other authors, too, highlight the commonplace association of the word with Statehood (Kiljunen 2004: 44; Piris 2006: 18; Stuart 2003: 10)

On this first definition, the claim that the text is a Constitution today - that it 'establishes a Constitution' today, as the title states - is clearly seen to be false. For the EU will remain composed of many States, rather than forming a single State in its own right, upon ratification of the text. There is a wide and firm consensus on this point (Bogdanor 2003: 52; Church and Phinnemore 2006: 10; Kiljunen 2004: 44; MacCormick 2005: 48; Patten 2005: 119, 155; Piris 2006: 190-197; Ziller 2005: 18).

Upon inspection of the body of the text, two factors in particular confirm this view. The first is that the process for future amendment of the text remains unaltered from the present situation: unanimous agreement of the member States in an IGC, followed by ratification according to respective constitutional requirements (Article IV-443). The document is not 'the last treaty under international law' (Grimm 2005: 207), and the process remains essentially external, based upon ratifying new amending treaties, not internal, based upon amending a Constitution. The fundamentals of the pre-existing treaty-making order, therefore, remain undisturbed. The second factor, referred to above, is that the member States have been attributed the ultimate right to reassert their sovereignty through withdrawal (Article I-60). As long as this clause remains in place, the EU cannot be said to possess territorial integrity, a fundamental characteristic of Statehood. Taken together, these two elements demonstrate conclusively that the EU is not, and will not in the near future become, a State.

The conceptual framework that Piris develops reinforces this conclusion. He notes first that '... the concept of 'Constitution' is often linked to the concept of 'State', whereas the purpose of (the document) is not at all to establish a federal State'. He then goes on to consider the 'final form' that the European project might take and lays out three possibilities: (i) a mere customs 
union with some common policies, (ii) a partially federal union with significant competences but mostly preserving the sovereignty of its constituent member States, and (iii) a fullyfledged federal State. 'It is worth stressing', he says, 'that (the text) gives the second answer to this question, clearly rejecting the other two' (Piris 2006: 18, 33) ${ }^{11}$.

So it seems clear that the text is not a Constitution on this first reading, because the EU will remain upon ratification a multi-State system.

We may simply observe here that the first definition frames treaties and Constitutions as mutually-exclusive notions. A treaty is an agreement between multiple States. A Constitution is constitutive of a single State. If many States, a treaty. If one State, a Constitution. A treaty is considered to be external to States (plural), an agreement between them in the realm of public international law; whereas a Constitution is considered to be internal to one State, constitutive of that State and the founding text of domestic law. There is no overlap between the two concepts. This is illustrated diagrammatically in Figure 1 below.

Figure 1: A Narrow Definition of the Term Constitution

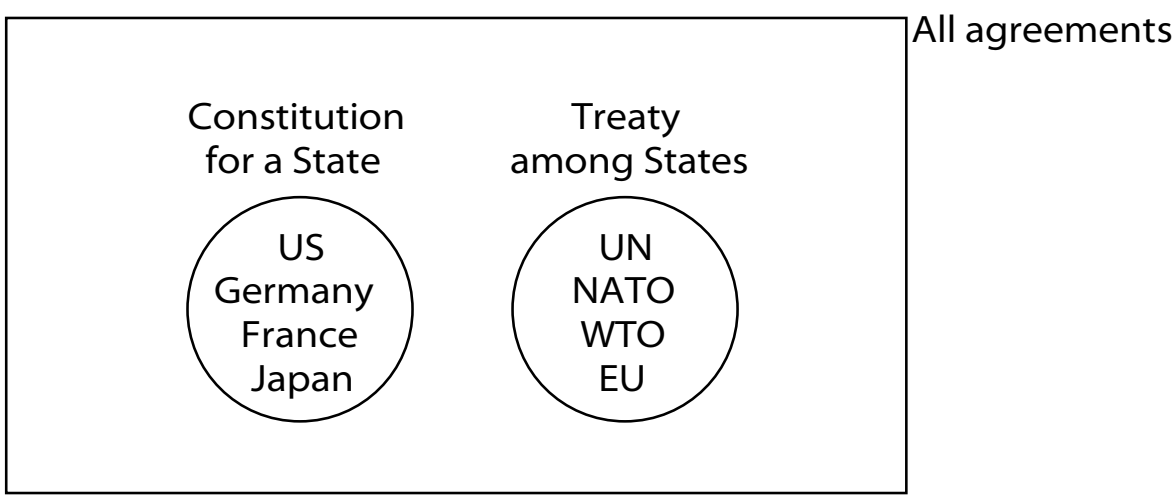

On a narrow interpretation of the term Constitution, the current European text could conceivably be either a Constitution or a treaty - a Constitution for a single pan-European State or a treaty among Europe's many nation States. Since we have established that the EU is and will remain composed of many States, the text must be considered a treaty and this alone.

The document could not be both Constitution and treaty simultaneously, for the reason that the EU and its nation States could not both possess Statehood at the same time; this quality must pertain to one or other level. To place the two nouns together in the same title, therefore, appears in this first case erroneous.

It is important to note, however, that treaties have in the past been the medium via which genuine Constitutions for new States have been created. Indeed, Grimm notes that this has traditionally been the 'standard procedure where several states combine to create a greater political whole' (Grimm 2005: 207). However, in this mechanism they cease to be treaties in practice the moment they enter force, by virtue of the revised amendment procedure which defines the (final) change of order from many States linked by a treaty between them to one State with its own Constitution. Upon inauguration of the text, what was external now becomes internal, with future amendments decided upon by the 'entity so constituted' (i.e. by majority vote and no longer by unanimity). As has been noted, legal and political scholars are in agreement that this is not the case for the proposed European document: the amendment procedure remains unchanged and the text will remain a treaty upon ratification (Church and Phinnemore 2006: 9, 35; Kiljunen 2004: 44, 46; Piris 2006: 186; Shaw 2005: 1; Ziller 2004: 18-19). So the text, therefore, cannot plausibly be claimed to be a Constitution. As Grimm observes: '... During the decision-making phase, everything remains as it was before. An IGC, which is 
not an organ of the EU, has to approve the draft unanimously - with or without amendments and then submit it to the member states for ratification. ... The document remains in the hands of the member states. Measured against a somewhat meaningful notion of a constitution, this document cannot be considered a constitution' (Grimm 2005: 208).

Definition (ii): A Constitution as the Founding Document of either a Single State or a Multi-State Political System

A second approach is to adopt a broader definition of the term Constitution to allow for the possibility that Europeans are actually engaged in something new: creating a Constitution for a multi-State political system. The term Constitution is here being deliberately expanded (one might say, crudely, 'bent') to fit with innovative practice. This is certainly possible; indeed, it is often how political terms and concepts evolve.

On this wider reading, there is now room for overlap between the concepts of treaty and Constitution, since the meaning of the term Constitution is enlarged to encompass both single and multi-State political systems. This is represented in Figure 2.

Figure 2: A Broad Definition of the Term Constitution

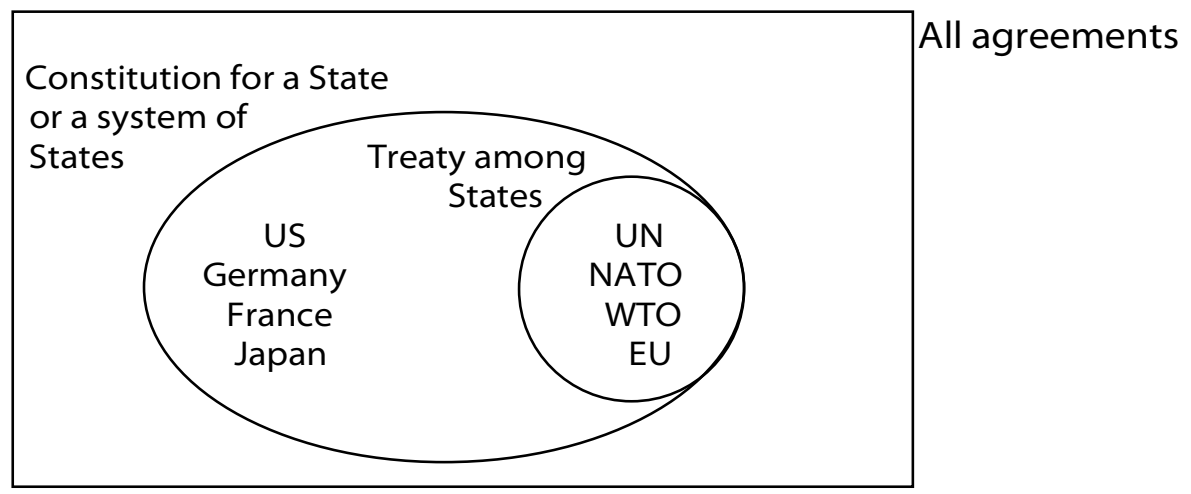

As the EU remains a multi-State political system, it clearly remains correct to describe the proposed EU text as a treaty; but it could also now, under this second definition, legitimately be described as a Constitution.

There are three significant problems with applying such an expanded definition of the term Constitution in justifying the title chosen by the Convention, however. We examine these in turn.

First, by the very nature of doing something new, there is an absence of convincing precedent which makes the concept difficult to sell to the public. There are two examples in existence of Constitutions for political organisations which are not single States: those of the International Labour Organisation (ILO) and of the World Health Organisation (WHO). However, as specialised agencies of the United Nations (UN), these bodies are inter-governmental organisations with a narrow technical-functional remit and are therefore far from close parallels for a comprehensive political system like the EU, which has representative institutions, its own legal order and competences in a very broad range of policy fields. Though perhaps not wholly invalid, these examples seem to offer only weak justification for the shift in the use of terminology proposed ${ }^{12}$.

A second difficulty is that attempting conceptual re-definition in the public mind of established and already well entrenched political notions, in the search for understanding and acceptance, would be an uphill struggle and a very steep one. The idea of a Constitution not for a single State but for a multi-State system is a difficult one to communicate to a sceptical 
public, already mistrustful of the advancing tentacles of European integration and easily alarmed by the prospect of a European super-State. As was noted above, accepted public usage of the term is at present different.

Thirdly, the perception that the document threatens to undermine national Constitutions and uproot the established basic framework of political ties and democratic connection between voters and their elected politicians at national level, presents a further enormous obstacle to surmount. Unfounded though this fear may be, seeking to overcome it through a tactic of public education alone, however well executed, appears a huge challenge.

Despite these three major reservations of pragmatism, however, it is still nonetheless logically sound to make an argument in favour of understanding the present EU text as one novel instance of a broad definition of the term Constitution, encompassing both single State and multi-State political systems.

Ziller is one author who is happy to follow this approach. He draws the conclusion that '... the Convention's text has in fact become a "Constitution" - but a Constitution adopted by the common agreement of the Member States of the Union in the form of a Treaty and not a Constitution of a collection of individuals designed to create a State' (Ziller 2005: 18).

Similarly, Kiljunen welcomes the notion of a Constitution for what he sees as cooperation in a 'supra-national union' broader than the nation State, but not a State itself. He says of the document: '... Legally speaking, it is an international treaty, and calling it a constitution will not turn it into the constitution of a state, because the Union it governs is not a state' (Kiljunen 2004: 46).

For Ziller and Kiljunen, then, and entirely consistent with this second definition of the term Constitution, the EU text is seen as both a treaty between States and a Constitution. On this wide definition, therefore, the title Treaty Establishing a Constitution for Europe is seen to be plausible.

Given the prevailing inauspicious political climate, however, this article argues that following such an approach now may not be the wisest course. Choosing to re-enter the same minefield at the second go and attempting to convince voters that an expanded definition of the term Constitution makes sense - that it is appropriate and not a threat - would be a decision involving great risk. A better plan may be to take a path around the minefield, if one exists.

Such are the two possibilities opened up by the competing perspectives of the term Constitution, narrow and broad, given under definitions (i) and (ii) above. Under definition (i), the EU text is conceived as a treaty but not a Constitution; whilst under definition (ii), it is seen as both a treaty and a Constitution. Under definition (i), the proposed title is erroneous. Under definition (ii), the proposed title is conceivable but difficult to sell to the public.

\section{Two Interpretations of the Word 'Establishing': Static and Dynamic}

At this point in the analysis, it is important to bring in an additional perspective which is currently playing a central role in muddying the waters of the debate. It will be argued that the possibilities this view opens up should be firmly excluded.

The perspective brings in a dynamic interpretation of the word 'establishing' in the phrase 'establishing a Constitution', alongside the existing static interpretation: that the text, as it has been agreed, is not a Constitution presently but is intended to become one at some point in the future - it is a Constitution in embryo. It will transform into such a document gradually over time. This will just happen - we will only know after the event.

Eleftheriadis calls the rationale for the assignment of a title which is not yet fully appropriate the 'instrumental argument', on the basis that it is the means by which the end will be achieved over time. He associates it with a theory called 'destiny theory' (perhaps better 
termed an 'ideology'), the fundamental premise of which is that normatively the goal of integration per se is understood to be 'a good thing ${ }^{\prime 13}$ (Eleftheriadis 2004: 7-11).

This additional dichotomy opens up a matrix of four possible permutations for interpreting the nature of the text (see Figure 3). Understood in this light, it is scarcely surprising that confusion abounds.

Box 1 (Figure 3) is shaded to highlight that this quadrant is inconsistent with the designation 'Constitution', as has been established above. In the three remaining quadrants, use of the word is argued to be conceivable.

Figure 3: Four Permutations for Interpreting the Phrase 'Establishing a Constitution'

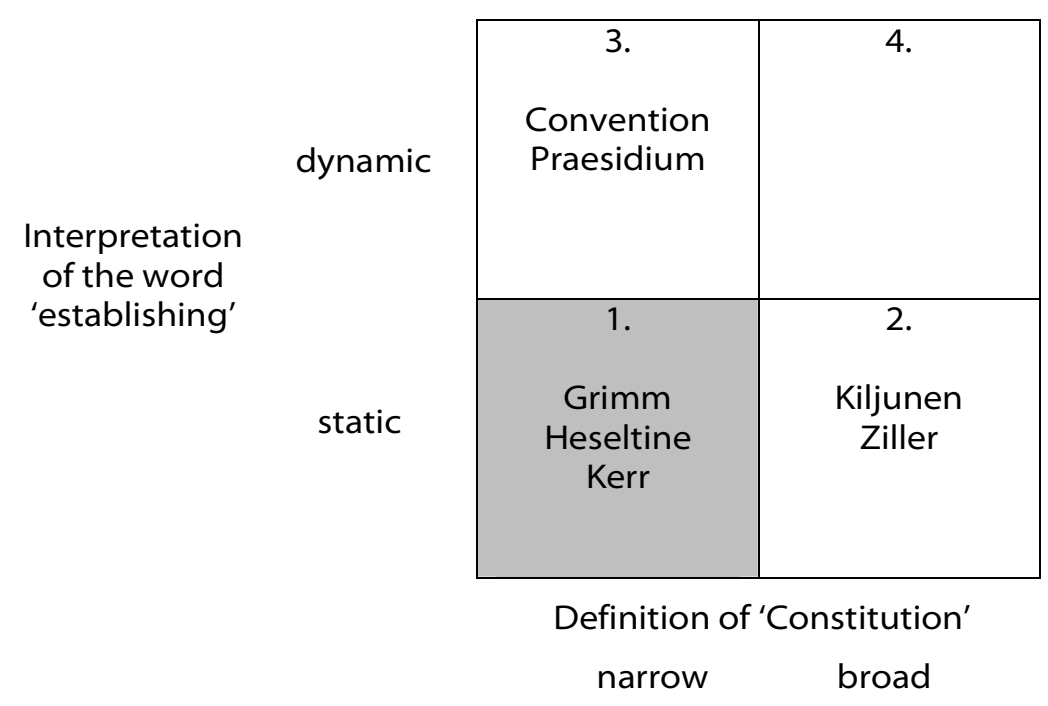

A narrow definition of the term Constitution coupled with a dynamic perspective of the word establishing (box 3 ) was probably the central view of proponents of a 'Constitution' label on the Convention Praesidium. On this understanding, whilst the text is presently a treaty between States and not a Constitution, it can nevertheless be viewed as laying the foundations for a genuine Constitution (for a State) in time, thus meriting the title attributed to it. The door is here being consciously left open to a more integrated future - a legacy bequeathed to future generations following the Philadelphia model.

Some or indeed many supporting this view may not have fully thought through the logical implications of their recommendation. Andrew Duff, following the original federal vision of Monnet and Spinelli in desiring a federal State, would not have felt the need to deny a goal of Statehood. The majority probably would have done, however, in which case they would have been forced onto the ground of accepting a broad definition of the term Constitution (boxes 2 and 4). Giscard might well have fallen into this camp. This position is consistent with the text remaining a treaty between States. So, one is left wondering why so much fuss was made over one word, fuss that cast in jeopardy ratification of the entire project. The emphasis put on deemphasising the treaty character of the document appears both inappropriate and a waste of effort.

This second dichotomy (static vs. dynamic) adds an additional layer of complexity, obscuring the clarity of the narrow vs. broad dichotomy of definitions (i) and (ii) above. The message being sent out to voters about the nature of the text becomes extremely mixed when the possibility of a forward-looking line of reasoning from a dynamic perspective is overlaid. The nuancing of the word 'establishing' upon which the logic of those in box 3 depends - that the text does not 'establish' a Constitution in the present tense but may do so incrementally over 
time - introduces an unwelcome haziness. Furthermore, the approach seems to run head on into the charge of seeking to create a federal State by stealth and lends fuel to the sceptics' claims (apparently here legitimate claims) that there is a hidden agenda to create a federation 'by the back door', rather than employ the mechanisms of open and transparent democratic process. If this is not the case, it might be better not to give this impression by ruling out the possibility.

No other European treaty prior has deployed a dynamic interpretation of the word 'establishing' in its title. On each occasion that it has been used (the Treaty of Paris, the two Treaties of Rome, the failed European Defence Community Treaty and the first draft of the TEU), it has been used to refer to a present action creating an entity with immediate effect. The novel slant on the word introduced in recent discussions is clearly unhelpful; we should be explicit in rejecting it.

If this is given effect, the number of possible permutations of the way in which the title of the text could be interpreted falls from four to two, a much more manageable number. The argument can then be had between two clear possibilities. This is shown in Figure 4. Following the discussion above, on a static view only under a broad definition of the term Constitution is the existing title plausible (box 2).

Figure 4: Excluding the Dynamic Interpretation

Interpretation of the word 'establishing'

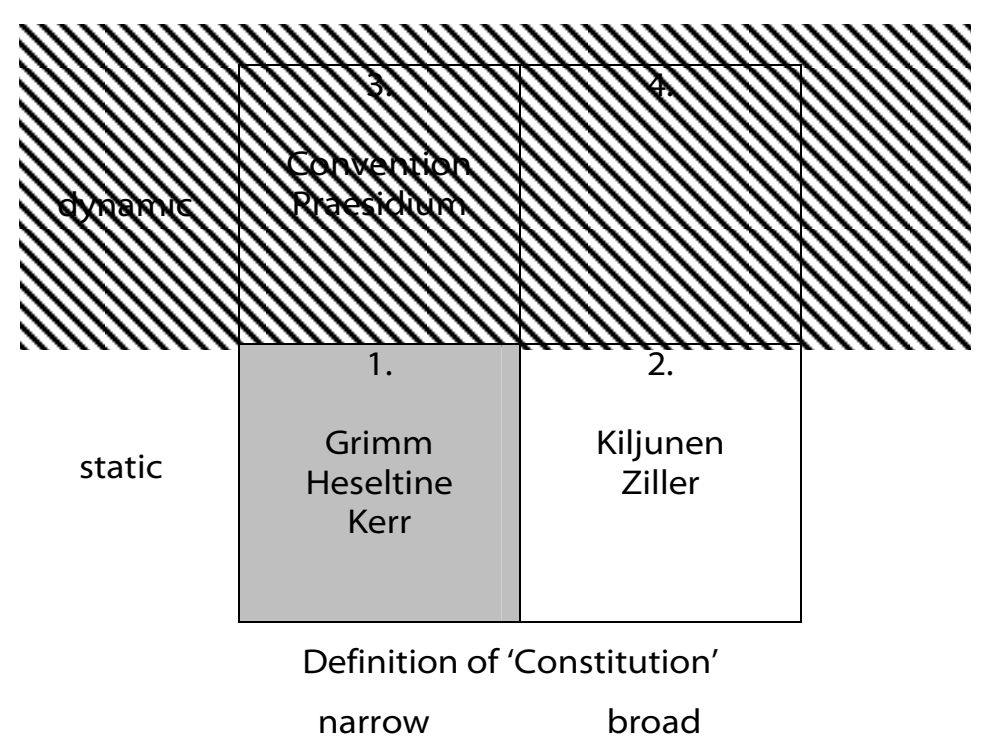

Of course, the dynamic approach (as under box 3 ) is not the view of things in national capitals. Secure in the knowledge that they remain 'masters of the Treaties', with a veto over any future treaty amendments, the perspective of the member States is that no fundamental shift in the locus of power could come about without their express and unanimous approval in an IGC (the same situation as now).

They do not, therefore, anticipate an unsanctioned shift of Statehood and ultimate sovereignty to the European level - as they hold the key. In their view, then, the text remains 'technically a treaty'. Of the two static options, they are clearly forced to accord with box 2 , an expanded definition of the term Constitution encompassing both single and multi-State political systems, in seeking to justify the title given to the text.

If this framework of analysis is correct, one of the most glaring missed opportunities of recent times appears to have been the national governments' failure to tone down the wording of the title at the IGC stage, to bring appearance back closer into line with underlying substance. Through their inaction, they were arguably guilty of tacit acquiescence in the mis-selling of the product. 
The IGC sat from September 2003 through to June 2004, beginning under the Presidency of the Italian Government and concluding under the Irish Government. The weight and importance of the handful of outstanding issues to be addressed was such that a conclusion to proceedings was not possible at the European Council meeting of December 2003, due to the refusal of Spain and Poland to agree to a reformed system of qualified majority voting (Church and Phinnemore 2006: 26-27; Piris 2006: 49-55). The noise generated by this and other contentious, predominantly institutional, issues perhaps distracted the member States from paying due attention to the labelling that had been attached to the product. In equal measure, there was a general reluctance to re-open the compromises already reached in the Convention; the Presidency at the helm would have feared adding yet another potentially divisive issue to the list of outstanding items still to be settled.

Whatever the true cause of the governments' inaction, the failure to adjust the title in order to bring out more clearly to the public the central quality of the text as remaining fundamentally a treaty in nature - when the media had latched exclusively onto the other word in the title, styling the document just 'the EU Constitution' - seems a costly oversight. This is, however, perhaps not a mistake which it is yet too late to correct.

\section{Constitutional Yes, Constitution No}

Certainly, the document has aspects that are constitution-like in character. Ziller holds the EU system up in the light of the constitutional thinking of the Enlightenment and brings out clearly three respects in which the text meets well the central characteristics of this tradition: (i) it provides a framework of rights; (ii) it orders the relationship between governors and the governed; and (iii) it institutes a system of checks and balances through a clear separation of powers (Ziller 2005: 2-10).

Shaw considers the EU system to represent a 'partial and evolving constitutional framework'. This evaluation seems about right. She sees the proposed text strengthening many important constitutional elements, which included '... aspects of the structure of the polity (legal personality; 'depillarisation', etc.) and ... some strides towards increasing the effectiveness of the Union and its capacity to operate as a legitimate forum for governance in which citizens are given both participatory and representative mechanisms through which they can express their preferences' (Shaw 2005: 1). The writings of other authors corroborate this view of an incrementally emerging constitutionalism (Eleftheriadis 2004: 3-4; MacCormick 2005: 17-25; Piris 2000: 6-16).

So we can certainly identify embryonic constitutional elements that are steadily evolving. It may be appropriate, then, to use the adjective constitutional to convey this sense of real but nevertheless, at this stage, still limited and circumscribed constitutional development. However, to most minds, jumping from this rather conservative notion to the bold assertion that the text itself represents a (full-blown) Constitution seems too far a leap. Shaw takes this view, concluding that in spite of the above, '... it would none the less be wrong at this stage to call the document "a Constitution", given the heritage of the concept of constitution. ... to me it is a Constitutional Treaty, not a Constitution as such' (Shaw 2005: 1). Again here, other authors echo this point (Moreau Defarges 2004: 63; Patten 2005: 119).

In contrast to the approach of Ziller and Kiljunen, this group prefers to restrict use of the term Constitution to its narrow sense, connected to Statehood, as under definition (i) above. In common with Kerr, Heseltine and Grimm, they regard employment of the word 'Constitution', standing alone as a noun, as too far a leap and thus a misapplication. They prefer instead to retain 'treaty' as the noun whilst admitting use of the word 'constitutional' as a qualifying descriptive adjective.

From the entire analysis to this point, therefore, perhaps rather surprisingly, we can in fact draw out quite a high degree of consensus as to the character of the document. Most 
observers (if not all) are comfortable designating it as a treaty (noun) with constitutional (adjective) aspects.

We must also recognise that it is not necessarily wrong to style the document as a 'Constitution': if it is accepted that Europeans are consciously choosing to adopt a novel and broad definition of the term 'Constitution', encompassing political systems composed of multiple States (as under definition (ii) above), the designation of the text as a Constitution need not be seen as inconsistent with the simultaneous assertion that it also remains a treaty. For on this reading, there is overlap between the concepts of treaty and Constitution. Thus, the notion that a treaty can 'establish' a Constitution is seen not to be entirely far-fetched.

However, for reasons of pragmatism, given that one major public crisis of confidence in European integration has already occurred, it is proposed here that an alternative route be taken out of the current impasse. Rather than a second heroic full-frontal assault in persisting with 'Constitution' as a noun, likely to be in vain, it is suggested that an easier path be taken around the obstacle that Europe finds lying in its path. For, as was noted above, choosing to adopt a broad definition of the term 'Constitution', though logically sound, brings with it significant problems. Even if the case is well made and consistently presented in public debate second time round, obstacles such as an absence of precedent, difficulties in shifting public perceptions and the perceived threat to existing national Constitutions may well prove too difficult to overcome.

What, then, might be possible alternative characterisations for the text to replace the current 'EU Constitution'? Two credible short form designations can be identified, (i) 'Constitutional Treaty', and (ii) 'Constitutional Charter'14. Each is considered in turn.

\section{(i) Constitutional Treaty}

The first option follows logically from the commentary of the large group of authors cited above. It reinstates the original formulation of the Convention, before the last-minute tinkering, 'Constitutional Treaty' (in full Constitutional Treaty for Europe). This designation appears technically accurate: a treaty with constitutional aspects.

There is one major problem with seeking to move back to this formulation now, however. This is that the meaning of, and the rationale for, the change would not be immediately obvious to the citizen - nor even would it become wholly apparent upon extensive explanation: it would simply appear to the man in the street as 'playing with words'. It would not anyway stand out that there had been substantial change, as the terms 'Constitution' and 'Constitutional Treaty' were both in currency on the first ratification attempt and used interchangeably by many. In consequence, it is not assured that the media would feel the need to revise their all-important shorthand designation away from 'EU Constitution'. These are sufficient grounds alone to reject this path. It seems crystal clear that meaningful and plainly evident change is required.

In spite of German Chancellor Angela Merkel's (correct) assessment that the term 'Constitutional Treaty' was 'not so bad' (Taylor 2006), we should be reluctant to follow the same route again.

\section{(ii) Constitutional Charter}

A second, and more promising, option would be to adopt the principle already employed by the Convention elsewhere in the draft text of codifying the accepted judgements of the European Court of Justice (ECJ) - as was done, for example, for the principles of primacy and direct effect of EU law.

Piris sets out clearly the position taken by the ECJ in designating the Treaties a 'constitutional charter', first in its judgement Les Verts of 1986 and on several subsequent occasions since. This ruling stated: '... (the EC is) a Community based on the rule of law, inasmuch as neither its 
Member States nor its institutions can avoid a review of the question whether the measures adopted by them are in conformity with the basic constitutional charter, the Treaty' (Piris 2000: 8).

One is struck by the apparent restraint of the judges here, in treading carefully when approaching the frontiers of national sovereignty. Their term appears suitably reserved, yet still clearly a significant advance on a conception of the EU's foundations as purely those of an international organisation.

Of note is that Piris himself, when writing prior to the start of the revision process in 2000, advocated a reformulation of the existing treaties into a short 'Treaty Charter' with longer protocols annexed to the back, where he suggested locating the more technical parts such as the detailed legal bases for the various policy fields. In making this proposal, he clearly followed and supported the ECJ's characterisation. A Treaty Charter, he said, '... would not change much legally, and the Treaties would not become a Constitution like that of a State as a result, but it could change things psychologically and politically' (Piris 2000: 41).

A marginal modification (or 'clarification') of the title of the existing text, then, taking up Piris' lead and codifying the ECJ's designation into Treaty Establishing a Constitutional Charter for Europe, appears to offer a promising way out of the present dilemma.

We can identify three major benefits linked with this specific proposal:

First, the media would have a clear prompt - and requirement - to readjust their short form title, in order to keep pace with the progressing evolution of the political debate, and the all important sound-bite would thus shift from 'EU Constitution' to 'EU Constitutional Charter'. The wave of publicity generated in making this change, if clearly and consistently explained and justified by politicians, could be sufficient to allow the public to feel that the political élite has listened to their concerns and that meaningful change has been implemented.

Secondly, aiding this process of explanation, there is a solid rationale for the term's introduction in the practice of codifying well-established but presently unwritten legal principles, as deployed elsewhere in the text.

Thirdly, the term Charter is understood in law to be of the order of a treaty between States ${ }^{15}$; so the change would help slay the myth of the underhand creation of a super-State, thus quashing convincingly the Euro-sceptics' main argument.

From a negative angle, it could be argued that past and present employment of the term charter by the EU has been in the context of documents more of a declaratory and nonbinding nature (for example, the Social Charter, the European Energy Charter and the Charter of Fundamental Rights). The proposed text, of course, also incorporates the Charter of Fundamental Rights in Part II of the document. Although perhaps not an ideal back-drop, it is argued here that such usage should not be allowed to stand in the way of its further application in the manner proposed. Alternative formulations offering a credible potential solution are in short supply today.

One further significant advantage, connected to seeking to implement change through modification of the title, is that the delicate package-deal struck in the Convention balancing a wide range of interests would not be re-opened. The eighteen member States that have already ratified the first document would not have to go through lengthy procedures again; short amending bills would suffice.

The re-naming suggested would represent a rational response by the EU and one based upon principle: identifying the problem and then correcting it. How better to confront the public's evident scepticism concerning the text, than for the European Council to accept a share of the responsibility, in this regard, and say: 'Sorry, we got it wrong. The nature of the document was not clear from the title given it by the Convention. We hope this new title clarifies the situation'. This would seem to meet the evident requirement for humility, an apparent pre-requisite if the failed referenda are to succeed on a second occasion. 


\section{Conclusion}

Having set off on our journey anxious to identify the cause of Europe's present constitutional crisis, we have now arrived at our destination. The source of the difficulties Europe faces has been firmly located; but perhaps just as importantly, a potential means of addressing them has been identified.

First, the Convention's text was established as a sensible and balanced package of reforms, a tidying-up exercise 'plus': the right product. Next, the prime cause of all the trouble was located not in the text itself but in the over-ambitious label given to it: the wrong packaging. It was observed that there is a broad range of possible interpretations of the phrase 'establishing a Constitution' in the title of the document, which introduces an unhealthy, and equally an unnecessary, element of confusion.

Although under one definition of the term 'Constitution' the title was seen to be plausible - a broad definition encompassing a political system of multiple States - for practical reasons it was argued that this possibility should be excluded from the present range of options. Instead, in view of the wide consensus that the document represents a treaty (noun) with certain partial and evolving constitutional (adjective) aspects, it was suggested that the ECJ's prevailing designation of the EU Treaties as a 'Constitutional Charter' be adopted. A modified title would thus read Treaty Establishing a Constitutional Charter for Europe.

This proposed revised title is not over-stated: it is measured and appropriate. It does not appear to make any over-ambitious claim for the text to be a full-blown Constitution, analogous to that of a State. Instead, the term Constitutional Charter clearly makes a lesser claim and the over-riding character of the text as a treaty would not be obscured. The UN has a Charter. The EU would have a Constitutional Charter. This seems right and appropriate. It represents well the stage of political development that Europe has now reached: a strong union of States and peoples.

I would like to thank Dr. Kalypso Nicolaidis of St. Antony's College, Oxford and John Pinder, Honorary Professor of the College of Europe, Bruges for their comments on this article and the Economic and Social Research Council for its financial support of the doctoral studies during which it was prepared.

\section{Notes}

${ }^{1}$ The Convention on the Future of Europe sat in Brussels from February 2002 to July 2003 with a mandate to prepare recommendations, or in the absence of consensus a set of options, for amending the existing European Treaties. It brought together in a unique formation members of national governments, national parliaments, the European Parliament and the European Commission.

${ }^{2}$ At Maastricht, Denmark secured 'clarifications' in the areas of citizenship, the single currency, defence, and justice and home affairs, in the form of a declaration of the Edinburgh European Council of December 1992. Similarly with the Nice Treaty, Ireland secured confirmation of her right to remain militarily neutral in a declaration of the Seville European Council of June 2002.

3 The findings of the post-referendum surveys by Eurobarometer bring out clearly the lack of cross-over (Eurobarometer 2005a; Eurobarometer 2005b). In descending order of importance, the reasons given by voters for voting No in France and the Netherlands, respectively, were:

France:

- the Constitution would have negative effects on employment in France (31\%)

- the economic situation in France was too weak / there was too much unemployment (26\%)

- economically speaking, the draft was too 'liberal' (19\%) 
- opposition to the President of the Republic, the government or to certain political parties (18\%)

- there was not enough 'social Europe' (16\%)

- the Constitution was too complex (12\%)

The Netherlands:

- the lack of information (32\%)

- the loss of national sovereignty (19\%)

- opposition to the national government or to certain political parties (14\%)

- the 'costs' of Europe (13\%)

It seems, as Giddens rightly says, that '... the reasons for the rejection of the constitution were not primarily to do with the document itself' (Giddens 2006). He goes on to state that '... the referendums in France and the Netherlands provided a vehicle for the expression of much wider discontents about employment, living standards and migration'. This second claim does represent the general received wisdom at present; however, it only seems, on close inspection, to be supported by the above evidence in loose terms. The perception of a threat to the economic system or 'social model' from globalisation, it appears from the data, was primarily a French concern. Nicolaidis brings out the uniqueness of the French outlook, observing that in France alone did the Left oppose the text. This, she says, contrasted strongly with the fact that '... every socialist and social democratic party in Europe - except for Malta favoured the constitution and so too did the great majority of trade unions'. The crisis it seems was as much to do with France herself, and her position in a rapidly changing world, as it was to do with Europe. What was new this time, Nicolaidis points out, was the French Left's advocacy of '.. . a type of pro-European No; that is, making credible the idea that No really meant Yes to "another Europe"' (Nicolaidis 2005: 13-14).

Yet, such a vision was never a realistic proposition. The document added little new to the existing 'acquis' on Single Market matters. The principle of 'free and undistorted' competition (Article 1-3.2) that raised so many hackles, for example, was not a new notion but merely a restatement of existing practice, as it has been rightly observed by many commentators. So the grounds for searching for, and the feasibility of finding, a new economic settlement among the now twenty-seven member States of the EU appear limited today. The legislation to implement a large internal market free of impediments to trade, balanced with redistributive and social elements (the Common Agricultural Policy, the structural funds and worker protection initiatives under the Social Charter and other directives), has been built up incrementally over the past half-century of integration, culminating in today's carefully weighted compromise. Equally, externally a clear majority of member States continue to favour openness to trade in the face of globalisation, rather than a protectionist response.

The tools to react to public concerns about unemployment and economic restructuring, say the critics of the French No on economic grounds, are to be found at national, not European, level (Giddens 2006; Piris 2006: 22). So it is from within national politics that solutions must be sought.

${ }^{4}$ Patten says: '... The Constitutional Treaty was widely regarded in the rest of Europe as a triumph for the predominately "British" view of how the EU should work' (Patten 2005: 129); and Ziller observes that '... the UK ... obtained more concessions than any other Member State - both in the Convention and during the IGC' (Ziller 2005: 129).

${ }^{5}$ Jean-Claude Piris is Director-General of the Legal Service of the Council of Ministers and was Legal Advisor to the Inter-governmental Conference.

6 In the famous 'Schuman Declaration' of 9 May 1950 proposing the first European Community in coal and steel, which Jean Monnet had drafted for the French Foreign Minister Robert Schuman, Monnet had included the explicit goal of a 'European federation'. In Article I60 we see, arguably, the first clear evidence of a definite break with the original vision of a federation / federal State (which, it must be recognised, was a very early general vision of the promised land), in favour of a more confederal design, a confederation of States conceived in strong form. This model should probably nevertheless also be considered a 'federal' form, that is to say confederalism defined as part of federalism, not in opposition to it. Interestingly, in concluding his Memoirs in the late 1970s, Monnet showed an increasing openness to a confederal vision of the finalité politique, and one concrete manifestation of it in particular, the European Council.

Leaving to one side, however, the evolution of Monnet's own thought, in an earlier period when more tenaciously attached to federation as a destination, Monnet had made plain the 
fact that no federation could incorporate a voluntary right of exit (the point at issue here): 'The withdrawal of a State which has committed itself to the Community should be possible only if all the others agree to such withdrawal and to the conditions in which it takes place. This rule in itself sums up the fundamental transformation which the French proposal seeks to achieve. Over and above coal and steel, it is laying the foundations of a European federation. In a federation, no State can secede by its own unilateral decision. Similarly, there can be no Community except among nations which commit themselves to it with no limit in time and no looking back' (Monnet 1978: 326).

7 To name but two examples of very positive house-keeping, two thousand eight hundred pages of primary law were reduced massively to five hundred and sixty, and the number of legal instruments was cut from fifteen to just six (Piris 2006: 58, 71).

${ }^{8}$ Giscard had declared the designation Constitutional Treaty the one to be used throughout proceedings, telling the inaugural meeting of the Convention on 28 February 2002: '... If we were to reach a consensus on this point (a single proposal), we would thus open the way towards a Constitution for Europe. In order to avoid any disagreement over semantics, let us agree now to call it: a "constitutional treaty for Europe"' (Giscard 2002: 20).

9 Regarding the modification to the title, it seems the change went undebated in the Convention. Gisela Stuart, a member of the directing Praesidium, offers a pessimistic account of internal Convention procedure, critical of what she saw as Giscard's autocratic management style and the lack of discussion on many substantive points at issue (Stuart 2003: 19-30). In the final stages of the Convention the body had many pressing questions of content to resolve and the issue of how to label the text, it appears, went to some degree lost in the mêlée. Giscard's line appears to have been that there was no time for 're-opening' the question, which had already to his mind been satisfactorily aired at the start of the Convention.

${ }^{10}$ The French voted No on 29 May 2005 by $55 \%$ to 45\%. The Dutch voted No three days later on 1 June 2005 by $62 \%$ to $38 \%$. Although the latter is a more substantial margin, commentators seem agreed that Dutch voters were emboldened by the French No and, freed of inhibitions and any likely consequences for their country, registered a protest vote in numbers larger than might otherwise have been the case.

11 The characterisation by Piris of the EU as a 'partially federal union' appears entirely consistent with this author's interpretation of the emerging finalité politique elaborated in Footnote 6.

12 To stretch credibility even further and claim the existence of a precedent in the Constitutions of golf clubs and political parties, on the basis that any 'rule-book' or framework for action within an organisation can legitimately be described as a Constitution, as British Foreign Secretary Jack Straw argued (Straw 2002), risks trivialising the debate and incurring voter suspicion and mistrust as a result.

${ }^{13}$ For reasons other than the paternalism inherent in this approach, Eleftheriadis concludes by rejecting it. This leads him firmly and explicitly to prefer the characterisation of the text as a treaty rather than a Constitution.

${ }^{14}$ Other formulations, such as 'Basic Treaty', hold attraction in some quarters. However, the phrase appears to draw its inspiration too heavily from the German Grundgesetz or Basic Law, the German Constitution. Too close a parallel with any one national model would be unwelcome in a European setting. Equally, Church and Phinnemore remark than simply seeking to 'relabel' the Constitutional Treaty as a 'Treaty' would be wholly unconvincing (Church and Phinnemore 2006: 172). It does seem both relevant and necessary to retain some form of reference to the constitutional-type nature of the text.

15 The Treaty Reference Guide of the UN Treaty Collection makes the point succinctly. It identifies charters as one of several 'international instruments binding at international law' falling under the generic heading of 'treaty', the full range being: 'treaties, agreements, conventions, charters, protocols, declarations, memoranda of understanding, modus vivendi and exchange of notes'. It observes that all of these types of agreement have broadly the same legal effect: '... Although these instruments differ from each other by title, they all have common features and international law has applied basically the same rules to all of these instruments' (United Nations 1999: 1). It goes on to note that the common rules referred to are found in the 1969 Vienna Convention on the Law of Treaties. 


\section{References}

Bogdanor, V. (2003). 'Federalism and the Nature of the European Union' in K. Nicolaidis and S. Weatherill (eds) Whose Europe? National Models and the Constitution of the European Union, Oxford University Press.

Burgess, M. (2006). Comparative Federalism: Theory and Practice, London, Routledge.

Burgess, M. (2000). Federalism and European Union: The Building of Europe, 1950-2000, London, Routledge.

Church, C. and Phinnemore, D. (2006). Understanding the European Constitution: An Introduction to the EU Constitutional Treaty, London, Routledge.

Convention on the Future of Europe (2002). Preliminary Draft Constitutional Treaty, 28 October 2002, CONV 369/02 at http://register.consilium.eu.int/pdf/en/02/cv00/00369en2.pdf.

Donnelly, B. (2005). Constitution or Constitutional Treaty?, Federal Trust Policy Commentary February 2005, at http://www.fedtrust.co.uk/publications.

Eleftheriadis, P. (2004). Constitution or Treaty?, Federal Trust Constitutional Online Paper No. 12/04, at http://www.fedtrust.co.uk/constitutionalpapers.

Eurobarometer (2005b). The European Constitution: Post-referendum survey in The Netherlands, Flash Eurobarometer 172, TNS Sofres c/o EOS Gallup Europe, at http://ec.europa.eu/public opinion/flash/fl172 en.pdf.

Eurobarometer (2005a). The European Constitution: Post-referendum survey in France, Flash Eurobarometer 171, TNS Sofres c/o EOS Gallup Europe, at http://ec.europa.eu/public opinion/flash/fl171 en.pdf.

Forsyth, M. (1981). Unions of States: the Theory and Practice of Confederation, Leicester University Press.

Giddens, A. (2006). 'Remember Europe', Prospect Magazine, November 2006, at http://www.prospect-magazine.co.uk.

Giscard, V. (2002). Introductory Speech to the Convention on the Future of Europe, 28 February 2002, in CONV 4/02 at http://register.consilium.eu.int/pdf/en/02/cv00/00004en2.pdf.

Grimm, D. (2005). 'Integration by constitution', International Journal of Constitutional Law, 3, pp. 193-208.

Heseltine, M. (2004). 'Yes: This Treaty is good for us', The Daily Telegraph, 26 April 2004.

Jeffery, S. (2005). 'Q \& A: The European constitution', The Guardian, 2 June 2005.

Kerr, J. (2003). 'Europe's treaty and the art of the possible', The Financial Times, 25 November 2003.

Kiljunen, K. (2004). The European Constitution in the Making, Brussels, Centre for European Policy Studies.

Laffan, B. (2002). The Future of Europe Debate, Dublin, Institute of European Affairs.

MacCormick, N. (2005). Who's Afraid of a European Constitution?, Exeter, Imprint Academic.

Menon, A. (2004). 'European Puzzle', Prospect Magazine, November 2004, at http://www.prospect-magazine.co.uk. 
Monnet, J. (1978). Memoirs, New York, Doubleday.

Moravcsik, A. and K. Nicolaidis (2005). The Future of the Constitutional Process of the European Union, Briefing Paper for the Constitutional Affairs Committee of the European Parliament, 1314 October 2005, at

http://www.europarl.europa.eu/meetdocs/2004 2009/organes/afco/afco 200510131500 sy mposium.htm.

Moreau Defarges, P. (2004). Comprendre la Constitution européenne, Paris, Editions d'Organisation.

Nicolaidis, K. (2005). 'The Struggle for EUrope', Dissent Magazine, Fall 2005, at http://www.dissentmagazine.org/archive.php.

Nicolaidis, K. (2004). 'We, the Peoples of Europe ...', Foreign Affairs, 83, pp. 97-110.

Nicolaidis, K. and R. Howse (eds) (2001). The Federal Vision: Legitimacy and Levels of Governance in the United States and the European Union, Oxford University Press.

Norman, P. (2003). The Accidental Constitution: The Story of the European Convention, Brussels, EuroComment.

Nugent, N. (2003). The Government and Politics of the European Union, Basingstoke, Palgrave.

Patten, C. (2005). Not Quite the Diplomat: Home Truths About World Affairs, London, Penguin.

Pinder, J. (2001). The European Union: A Very Short Introduction, Oxford University Press.

Piris, J.-C. (2006). The Constitution for Europe: A Legal Analysis, Cambridge University Press.

Piris, J.-C. (2000). Does the European Union Have a Constitution? Does It Need One?, Harvard Jean Monnet Working Paper No.5/00, at http://www.jeanmonnetprogram.org/papers.

Shaw, J. (2005). Briefing Paper for the Constitutional Affairs Committee of the European Parliament, 13-14 October 2005, at

http://www.europarl.europa.eu/meetdocs/2004_2009/organes/afco/afco_20051013_1500_sy mposium.htm.

Straw, J. (2002). 'A Constitution for Europe', The Economist, 11 October 2002.

Thomas, H. (1991). Ever Closer Union: Britain's Destiny in Europe, London, Hutchinson.

Stuart, G. (2003). The Making of Europe's Constitution, London, Fabian Society.

United Nations (1999). United Nations Treaty Collection Treaty Reference Guide, at http://untreaty.un.org/English/guide.asp.

Taylor, S. (2006). 'Merkel rejects ideas to restart constitution talks', European Voice, 28 September 2006.

Wallace, H., W. Wallace and M. A. Pollack (eds) (2005). Policy-making in the European Union, Oxford University Press.

Zielonka J. (2000). 'Enlargement and the Finality of European Integration' in C. Joerges, Y. Mény and J. Weiler (eds) What Kind of Constitution for What Kind of Polity: Responses to Joschka Fischer, Florence, European University Institute.

Ziller, J. (2005). The European Constitution, The Hague, Kluwer Law International. 